DOI: http://dx.doi.org/10.33846/ghs5312

\title{
Pengaruh Health Education Terhadap Perubahan Tingkat Pengetahuan Ibu Tentang Pemberian Imunisasi Balita di Desa Waimital
}

\author{
Nety Taribuka (koresponden) \\ (DIII Kebidanan, STIKes Maluku Husada) \\ Syariefah H Waliulu \\ (IImu Keperawatan, STIKes Maluku Husada) \\ Eva Dayanti Kene \\ (DIII Kebidanan, STIKes Maluku Husada)
}

\begin{abstract}
ABSTRAK
Pemberian imunisasi pada anak yang mempunyai tujuan agar tubuh kebal pada penyakit tertentu. Kekebalan tubuh juga dapat dipengaruhi oleh beberapa faktor diantaranya terdapat kadar antibodi yang tinggi pada saat dilakukan imunisasi, potensi antigen yang disuntikan, dan waktu antara pemberian imnunisasi. Jenis penelitian yang digunakan dalam penelitian ini adalah penelitian eksperimental. Penelitian ini menggunakan rancangan penelitian pra-eksperimental dengan pendekatan one-group pra-post test design. Media yang digunakan dalam penelitian ini adalah leaflet sebagai media health education untuk meningkatkan pengetahuan ibu. Hasil penelitian menunjukkan perbedaan pengetahuan ibu tentang imunisasi sebelum diberikan health education dan sesudah diberikan health education. Setelah dilakukan penelitian di desa Tomalehu selama 1 bulan dari tanggal 04 Agustus sampai 04 September 2019 dan berdasarkan hasil uji wilcoxon dalam output "Test Statistics" diketahui Asymp. Sig. (2-tailed) bernilai 0,000 lebih kecil dari $<0,05$ maka dapat disimpulkan bahwa "Ha diterima". Artinya ada perbedaan antara pengetahuan ibu pre health education ke nilai post health education.
\end{abstract}

Kata Kunci: pengetahuan; balita; imunisasi; health education

\section{PENDAHULUAN}

Imunisasi merupakan usaha memberikan kekebalan pada bayi dan anak dengan memasukkan vaksin ke dalam tubuh agar membuat antibodi untuk mencegah penyakit tertentu. Vaksin adalah bahan yang dipakai untuk merangsang pembentukan zat anti yang dimasukkan kedalam tubuh melalui suntikan seperti vaksin BCG, DPT, Hepatitis B, Campak dan melalui mulut seperti polio. ${ }^{(1)}$

Pemberian imunisasi pada anak yang mempunyai tujuan agar tubuh kebal pada penyakit tertentu. Kekebalan tubuh juga dapat dipengaruhi oleh beberapa faktor diantaranya terdapat kadar antibodi yang tinggi pada saat dilakukan imunisasi, potensi antigen yang disuntikan, dan waktu antara pemberian imnunisasi. Keefektifan imunisasi tergantung dari faktor yang mempengaruhinya sehingga kekebalan tubuh dapat diharapkan pada diri anak.(2)

Usaha-usaha yang dilakukan dinas kesehatan masih banyak mengalami kendala diantaranya kepatuhan orang tua untuk mengimunisasikan bayinya. Selain itu kesibukan orang tua, kurang sosialisasi dari pemerintah serta budaya setempat yang masih mengandalkan dukun menjadi faktor yang mempengaruhi kepatuhan orang tua untuk memberikan imunisasi pada bayinya. Kepatuhan merupakan suatu permasalahan bagi semua disiplin perawatan kesehatan. Kepatuhan dalam mengimunisasikan anak sangatlah penting untuk kesehatan anak dalam tahap tumbuh kembang. ${ }^{(2)}$

Ada beberapa faktor yang mempengaruhi ketidakpatuhan orang tua membawa anaknya untuk di imunisasi, antara lain orang tua yang sibuk bekerja, kurang memiliki waktu, bahkan kurang pengetahuan tentang imunisasi dan perhatian terhadap kesehatan anakpun berkurang, kurang informasi yang diperoleh oleh masyarakat baik melalui media massa, media elektronik maupun penyuluhan-penyuluhan serta budaya yang masih mengandalkan dukun sebagai penolong persalinan, sehingga tidak ada anjuran kepada ibu bersalin untuk mengimunisasikan bayinya. Hal ini menjadikan masyarakat tidak mengenal tentang imunisasi. ${ }^{(3)}$

Peran seorang ibu dalam program imunisasi sangat penting, sehingga pemahaman tentang imunisasi sangat diperlukan. Begitu juga dengan pengetahuan, kepercayaan dan perilaku kesehatan orang tua. Kurangnya so sialisasi dari petugas kesehatan menyebabkan masalah rendahnya pengertian, pemahaman dan kepatuhan ibu dalam program imunisasi. Berdasarkan data tersebut dapat disimpulkan bahwa upaya promotif dan preventif belum berjalan secara maksimal. ${ }^{(3)}$

Tingkat pengetahuan yang tinggi lebih mengetahui, memahami dan patuh dengan apa yang menjadi tanggung jawab untuk memenuhi kebutuhan anak yaitu dengan mengimunisasikan anaknya 
sesuai jadwal yang ditentukan. Demi tahap tumbuh-kembang anak yang optimal dan terhindar dari penyakit, dapat dicegah dengan imunisasi. Kesimpulannya bahwa ada hubungan yang bermakna antara tingkat pengetahuan ibu dengan pemberian imunisasi pada bayi.(3)

Tujuan yang hendak dicapai oleh World Health Organization (WHO) yang telah dirumuskan dalam pertemuan Atlanta tahun 1978 adalah mencapai sehat semua di tahun 2000, yang lebih dikenal denganHealth for all by year 2000. Upaya untuk mencapai tujuan ini berbagai program dengan berbasis Primary Health Care telah dilaksanakan untuk meningkatkan derajat kesehatan.

Kementerian Kesehatan Indonesia telah menyusun program sebagai usaha yang dilakukan untuk menekan penyakit PD3I pada anak, Seperti Program Pengembangan Imunisasi (PPI) pada anak sejak tahun 1956. Keberhasilan bayi dalam mendapatkan lima jenis imunisasi dasar (HB0, BCG, DPTHB, Polio, dan Campak) diukur melalui indikator imunisasi dasar lengkap. Data RIS KESDAS mencatat, tahun 2007 cakupan imunisasi dasar lengkap di Indonesia ratarata 41,6\%. Kemudian meningkat pada tahun 2010 dengan ratarata cakupan 53,8 \%. Tahun 2013 ratarata cakupan imunisasi dasar lengkap kembali meningkat yaitu 59,2\%, sedangkan target Renstra (88\%). ${ }^{(4)}$

Persentase cakupan imunisasi di Maluku pada tahun 2014 mencapai 82,26\%, cakupan ini menurun dari tahun sebelumnya yaitu $88,64 \%$ pada tahun 2013. Kabupaten Seram Bagian Timur merupakan Kabupaten dengan capaian imunisasi tertinggi 114,15\% sedangkan kabupaten Maluku Tenggara Barat, Buru dan kota Tual juga capaiannya diatas 100\%. Tiga kabupaten dengan capaian terendah adalah Buru Selatan, Aru dan Seram Bagian Barat. ${ }^{(5)}$

Desa Waimital merupakan salah satu desa yang berada dikecamatan Kairatu dan merupakan wilayah kerja dari Puskesma Waimital. Dimana pada desa Waimital ini jumlah kunjungan balita terbilang cukup rendah. Jumlah kunjungan menurun tiap bulannya. Pada tahun 2014 jumlah balita yang mendapat imunisasi lengkap sebanyak 42 orang. Hal ini meningkat pada 2015 yaitu 62 orang yang terhitung dapat imunisasi lengkap. Di tahun 2016 jumlah balita yng terdaftar mendapat imunsasi lengkap kembali menurun yaitu 43 balita. Sedangkan pada tahun 2017 kunjungan kePosyandu semakin menurun, menurut data dari Kepala Desa Waimital jumlah balita yang harusnya masih mendapat imunisasi sebanyak 123 balita. Namun data dari Puskesmas Tomalehi jumlah balita sampai Juni 2017 hanya mencapai 39 balita yang masih mengikuti imunisasi sedangkan 84 balita lainnya tidak mengikuti imunisasi.

Berdasarkan survei pendahuluan yang dilakukan peneliti terhadap ibu balita di Tomalehu didapatkan banyak ibu yang tidak megetahui pentingnya imunisasi sehingga malas membawa anak untuk mengikuti Posyandu. Masyarakat juga mengatakan petugas kesehatan di Desa Tomalehu tidak pernah melakukan penyuluhan kesehatan tentang pentingnya anak mendapat imunisasi sehingga tidak ada atau kesadaran para ibu membawa balita untuk mengikuti posyandu tiap bulannya sangat kurang.

\section{METODE}

Jenis penelitian yang digunakan dalam penelitian ini adalah penelitian eksperimental yang merupakan suatu rancangan penelitian yang digunakan untuk mencari hubungan sebab akibat dengan adanya keterlibatan penelitian dalam melakukan manipulasi terhadap variabel bebas. ${ }^{\left({ }^{6}\right)}$

Penelitian ini menggunakan rancangan penelitian pra-eksperimental dengan pendekatan onegroup pra-post test design. Media yang digunakan dalam penelitian ini adalah leaflet sebagai media health education untuk meningkatan pengetahuan ibu balita tentang pentingnya imunisasi dan kuesioner untuk menilai tingkat pengetahuan ibu balita serta sasaran dalam penelitian ini adalah para ibu yang mempunyai anak balita. ${ }^{(7)}$

HASIL

Tabel 1. Hasil uji normalitas data

\begin{tabular}{|c|c|c|c|}
\hline Variabel & Mean & Std. Deviation & Asymp. Sig \\
\hline Pengetahuan Pre HE & 2,74 & 0,445 & 0,000 \\
\hline Pengetahuan Post $H E$ & 1,58 & 0,502 & 0,000 \\
\hline
\end{tabular}

Hasil uji normalitas kuisioner didapatkan nilai Sig. pada pre health education adalah 0,000 dan nilai Sig. pada post health education adalah 0,000. Dari hasil uji statistik ini dapat disimpulkan bahwa kedua kelompok data yaitu pengetahuan pre health education dan post health education adalah berdistribusi normal. 
Tabel 2. Distribusi responden berdasarkan pengetahuan pre health education tentang imunisasi

\begin{tabular}{|c|c|c|}
\hline Pengetahan Pre & Frekuensi & $\%$ \\
\hline Baik & 0 & 0 \\
Cukup & 8 & 25,8 \\
Kurang & 23 & 74,2 \\
\hline Total & 31 & 100 \\
\hline
\end{tabular}

Berdasarkan tabel 2 dapat diketahui bahwa sebelum diberikan pendidikan kesehatan tentang imunisasi pengatahuan dalam kategori cukup adalah 8 responden dan kategori kurang adalah 23 responden.

Tabel 3. Distribusi responden berdasarkan pengetahuan post health education tentang imunisasi

\begin{tabular}{|c|c|c|}
\hline Pengetahan Pre & Frekuensi & $\%$ \\
\hline Baik & 13 & 41,9 \\
Cukup & 18 & 58,1 \\
Kurang & 0 & 0 \\
\hline Total & 31 & 100 \\
\hline
\end{tabular}

Tabel 4. Pengaruh health education terhadap perubahan tingkat pengetahuan ibu tentang imunisasi

\begin{tabular}{|c|c|c|c|c|c|}
\hline Variabel & Mean & Std. D & Uji T & Sig. (2-tailed) & Standar \\
\hline Pengetahuan pre health education & 2,74 & 0,445 & 0,995 & 0,000 & $<0,05$ \\
\hline Pengetahuan post health education & 1,58 & 0,502 & 1,328 & 0,000 & $<0,05$ \\
\hline
\end{tabular}

Hasil analisis pada tabel 4 diperoleh nilai probabilitas sebesar 0,000 lebih kecil dibandingkan taraf signifikan $5 \%$ atau 0,05 , sehingga dapat disimpulkan bahwa ada pengaruh antara pengetahuan sebelum dan sesudah diberikan health education tentang imunisasi.

\section{PEMBAHASAN}

Proses penelitian ini dilakukan dengan cara membagikan kuisioner pada orang tua yang mempunyai anak balita. Setelah pembagian kuisioner dan kuisioner diisi oleh responden, kemudian kuisioner dikumpulkan. Setelah itu peneliti melakukan intervensi yaitu health education (pendidikan kesehatan), kemudian setelah melakukan pendidikan kesehatan peneliti membagi kuisioner untuk menilai kembali pengetahuan ibu balita. Data kuisioner kemudian diolah menggunakan program SPSS untuk mengetahui apakah perbedaan pengetahuan sebelum dilakukan health education dan sesudah dilakukan health education.

Hasil uji T diketahui Asymp. Sig. (2-tailed) bernilai 0,000 lebih kecil dari $<0,05$ maka dapat disimpulkan bahwa "Ha diterima". Artinya ada perbedaan antara pengetahuan ibu pre health education ke nilai post health education. Hal ini menunjukkan bahwa pendidikan kesehatan sangat berpengaruh terhadap pengetahuan dimana telah terjadi perubahan pengetahuan seperti yang diharapkan dari pendidikan kesehatan yaitu dari tidak tahu menjadi tahu. ${ }^{(8)}$

Selain kurangnya informasi dari petugas kesehatan setempat, tingkat pendidikan ibu yang rendah juga mempengaruhi tingkat imunisasi balita. Ibu dengan tingkat pengetahuan rendah cenderung memiliki informasi yang minim tentang pentingnya imunisasi sehingga tidak patuh membawa anaknya untuk mengikuti imunisasi setiap bulannya. Pada penelitian ini sebagain besar responden mempunyai tingkat pendidikan sebatas Sekolah Menengah Atas (SMA) sehingga pemahaman tentang pentingnya imunisasi juga sangat terbatas. ${ }^{(9)}$

Terjadi perubahan pengetahuan ibu balita tentang imunisasi karena adanya intervensi diberikan oleh peneliti. Sebelum dilakukan intervensi pengetahuan ibu terbilang sangat kurang, ini disebabkan karena paparan informasi tentang imunisasi yang jarang didapatkan dari petugas kesehatan setempat. Media eelektronik yang seharusnya merupakan ladang ilmu juga lebih sering dimanfaatkan untuk menonton film sehingga acara-acara yang berbau pengetahuan tidak pernah ditonton. ${ }^{(10)}$

Intervensi yang dilakukan oleh peneliti menghasilkan pengaruh yang baik terhadap pengetahuan responden. Pengetahuan yang awalnya sangat kurang akhirnya meningkat setelah diberikan pendidikan kesehatan. Para ibu juga mengatakan akan merubah kebiasaan yang jarang membawa anak kefasilitas kesehatan menjadi suatu rutinitas bulanan yang wajib dilakukan. ${ }^{(11)}$

Persepsi ibu untuk membawa anak untuk imunisasi juga kadang dipengaruhi oleh efek imunisasi yang mengakibatkan anak demam. Karena pengetahuan ibu yang rendah maka ibu tidak 
memahami jika demam yang terjadi setelah imunisasi merupakan respon imunitas tubuh atau penyesuain tubuh terhadap imunisasi yang diberikan. Akibatnya ibu tidak mau lagi membawa anak untuk mengikuti imunisasi pada jadwal imunisasi berikutnya. ${ }^{(12)}$

Hasil ini juga didukung oleh penelitian bahwa ada pengaruh yang bermakna dari pendidikan kesehatan dengan menggunakan leaflet terhadap peningkatan pengetahuan, ibu dan diharapkan nantinya pengetahuan ini dapat memotivasi ibu untuk dapat membawa anaknya untuk mengikuti imunisasi tiap bulannya. Karena termotivasinya seseorang dipengaruhi oleh tingginya pengetahuan yang diperoleh dari pendidikan kesehatan yang dapat berdampak positif dalam perubahan perilaku akibat proses belajar sebab belajar adalah proses perubahan dari tidak tahu menjadi tahu. ${ }^{(13)}$

Pendidikan secara umum adalah segala upaya yang direncanakan untuk mempengaruhi orang lain baik individu, kelompok atau masyarakat sehingga mereka melakukan apa yang diharapkan oleh pelaku pendidik, sedangkan pendidikan kesehatan adalah aplikasi atau penerapan pendidikan dalam bidang kesehatan. Aplikasi atau penerapan pendidikan kesehatan yang dimaksud adalah suatu bentuk intervensi atau upaya yang ditujukan kepada perilaku agar perilaku tersebut kondusif untuk kesehatan. Dengan perkataan lain pendidikan kesehatan mengupayakan agar perilaku individu, kelompok atau masyarakat mempunyai pengaruh positif terhadap pemeliharaan dan peningkatan kesehatan. ${ }^{(10)}$

Tindakan terbuat adalah dengan melakukan atau memberikan pendidikan kesehatan kerena pendidikan kesehatan merupakan proses perubahan perilaku secara terencana pada diri individu, kelompok, atau masyarakat sehingga mereka melakukan apa yang diharapkan oleh pelaku pendidik untuk dapat lebih mandiri dalam mencapai tujuan hidup sehat. ${ }^{(13)}$

Hal tersebut diatas menunjukan bahwa begitu penting peran pendidikan kesehatan dalam mempengaruhi perilaku manusia dalam meningkatkan pengetahuan dan sikap atau praktik akibat proses balajar sebab pendidikan kesehatan merupakan proses belajar pada individu, kelompok, atau masyarakat dari tidak tahu tentang nilai kesehatan menjadi tahu, dan dari tidak mampu mengatasi masalah kesehatan sendiri menjadi mandiri. Dengan demikian pendidikan kesehatan merupakan usaha atau kegiatan untuk membantu individu, kelompok, atau masyarakat dalam meningkatkan kemampuan baik pengetahuan, sikap, maupun ketrampilan untuk mencapai hidup sehat secara optimal.

\section{KESIMPULAN}

Pengetahuan ibu sebelum diberikan health education adalah sangat rendah (kurang), pengetahuan ibu setelah diberikan health education adalah mengalami peningkatan dari yang kurang menjadi cukup dalam memahami tentang imunisasi, ada perbedaan pengetahuan ibu sebelum diberikan health education dan sesudah diberikan health education

\section{DAFTAR PUSTAKA}

1. Hidayat, A.A.A. (2012). Pengantar ilmukeperawatan anak 1, Jakarta: Salemba Medika

2. Ayubi, D. (2013). Kontribusi Pengetahuan Ibu terhadap Status Imunisasi Anak di Tujuh Provinsi di Indonesia. Jurnal Pembangunan Manusia.

3. Wiastuti P. (2012). Faktor-faktor yang berhubungan dengan pemberian Imunisasi BCG Di Wilayah Kerja Puskesmas UPT Cimanggis Kota Depak Tahun 2012. Jurnal IImiah Kesehatan. 2012

4. Kementerian Kesehatan. (2013). Program Pengembangan Imunisasi (PPI). Jakarta: Pusat Data dan Surveilans Imunisasi Kementerian Kesehatan RI.

5. Dinkes Provinsi Maluku. (2013). Profillmunisasi ibu, bayi dan balita.

6. Notoadmodjo S. (2014). Promosi Kesehatan dan Perilaku Kesehatan. Jakarta: Rineka Cipta.

7. Nursalam, (2013). Konsep dan penerapan metodologi penelitian ilmu keperawatan. Jakarta: EGC.

8. Rahmawati Al. (2013). Faktor Yang Mempengaruhi Kelengkapan Imunisasi Dasar Di Kelurahan Krembangan Utara. FKM Unair.

9. S, Azwar. (2013). Sikap Manusia. Yogyakarta: Pustaka Belajar.

10. Septiana. (2014). Pengaruh Pendidikan Kesehatan Terhadap Tingkat Pengetahuan Remaja Tentang Kesehatan Reproduksi Di SMP Islam Ruhama Ciputat. Skripsi. Program Studi IImu Keperawatan Fakultas Kedokteran Dan Ilmu Kesehatan: Universitas Islam Negeri Syarif Hidayatullah

11. Soetjiningsih. (2012). Tumbuh Kembang Anak. Jakarta: Penerbit Buku Kedokteran EGC.

12. Widayati SN. (2012). Hubungan Tingkat Pengetahuan Ibu Tentang Imunisasi Polio Dengan Status Kelengkapan Imunisasi Polio Diwilayah Kerja Puskesmas Tanon I Sragen. Gaster. Volume 9

13. Baker, L.M, Wilson, F.L, Nodstorm, C.K, \& Lagwand, C. (2014). Mother knowledge and information need relating to childhood immunization. Pediatric Nursing 